\title{
Más allá de las tapias de los cementerios: la represión cultural y socioeconómica en la España franquista (1936-1951)*
}

\author{
Claudio Hernández Burgos \\ Miguel Ángel Del Arco Blanco \\ Universidad de Granada \\ chb@ugr.es ; maarco@ugr.es
}

Recibido: 02/05/2011

Aceptado: 07/07/2011

\section{RESUMEN}

El presente artículo pretende abordar de manera conjunta los perfiles de la represión franquista. El franquismo, como otros regímenes dictatoriales de la Europa de entreguerras, no puede entenderse sin el control social y la represión que ejercieron contra los sectores más desafectos de las sociedades sobre las que se construyeron. Por ello, para comprender los asesinatos cometidos en las tapias de los cementerios debemos mirar más allá. Así, se concibe la represión física, cultural y socioeconómica de manera integrada y complementaria, contribuyendo a ofrecer una explicación más sólida y compleja de la represión franquista. Para tal fin, se analizan en detalle la represión cultural y socioeconómica durante los años del primer franquismo.

Palabras clave: represión física, represión cultural, represión socioeconómica, franquismo, fascismo.

\section{Beyond the Cemetery Walls: Cultural and Socioeconomic Repression in Francoist Spain (1936-1951)}

\begin{abstract}
This article aims to deal with jointly the conception of Francoist repression. Like other dictatorial regimes of interwar Europe, Francoism cannot be understood without the social control and the repression exerted over the disaffected sectors of the society they established over. Thus, to understand the killings committed in the cemetery walls we should see beyond physical repression. Thereby, physical, cultural and socioeconomic repression are conceived in an integrated and complementary way, offering a more solid and complex explanation of Francoist repression. To this end, cultural and socioeconomic repression are analysed in the first years of Francoism.
\end{abstract}

Key words: physical repression, cultural repression, socioeconomic repression, Francoism, fascism.

Sumario: Introducción. 1. La Victoria lo inunda todo: la represión cultural en la posguerra. 2. Acorralados: la represión socioeconómica en el primer franquismo. 3. Conclusión.

${ }^{*}$ Este texto se enmarca en el proyecto I+D "La memoria de la Guerra Civil, las "culturas de la victoria' y los apoyos sociales al régimen franquista, 1936-1950”, patrocinado por el Ministerio de Ciencia e Innovación desde el año 2010. 


\section{Introducción}

Las olas de lo que fue el régimen de Franco no cesan de golpear nuestro presente. Tras décadas de silencio, a cada día, a cada instante, nos vemos asaltados por fotogramas del pasado de la dictadura. La mayoría de ellos se refieren a la brutal represión física sobre la que se construyó el franquismo. Fosas comunes en cementerios, cunetas y barrancos. Restos humanos aún por identificar. Y todo, ante los tristes ojos de las familias que presencian las exhumaciones. Esas imágenes, esos rastros, son la mayor evidencia sobre la represión física del franquismo. Pero el universo represivo del franquismo fue mucho más amplio de lo que esos dramáticos restos del pasado nos dejan ver.

Por lo menos desde comienzos del presente siglo, trabajos pioneros comenzaron a ofrecer un espectro más amplio de la represión, llamando la atención sobre la represión socioeconómica y cultural.' Siguiendo esta línea, progresivamente otros estudios locales y regionales hicieron un esfuerzo por integrar estas variables en sus análisis, contribuyendo así a explicar el nacimiento y consolidación del régimen franquista. ${ }^{2}$ Posteriormente, monografías generales sobre la represión han comenzado a integrar algunos de estos aspectos represivos. ${ }^{3}$ El presente artículo se enmarca en esta tendencia, contribuyendo a ensanchar los perfiles de la represión franquista. En las páginas siguientes hacemos un esfuerzo por ofrecer una visión más amplia y, sin duda más funesta, del carácter represivo del "Nuevo Estado". El franquismo, como otros regímenes dictatoriales de la Europa de entreguerras, no puede entenderse sin el control social y la represión que ejercieron contra los sectores más desafectos de las sociedades sobre las que se construyeron. Por ello, para comprender los asesinatos cometidos en las tapias de los cementerios o los consejos de guerra tras la firma de la paz, debemos mirar más allá de la represión física. Debemos ahondar en el análisis de la represión cultural y socioeconómica, objeto último de este texto.

Represión física, represión cultural y represión socioeconómica fueron los tres pilares de la violencia política del franquismo. Como sostiene la tesis central del presente texto, somos partidarios de concebirlos de manera integrada y complemen-

${ }^{1}$ MIR, Conxita: Vivir es sobrevivir. Justicia, orden y marginación en la Cataluña rural de posguerra. Lérida, Milenio, 2000.

${ }_{2}^{2}$ COBO ROMERO, Francisco y ORTEGA LÓPEZ Teresa: Franquismo y posguerra en Andalucía Oriental. Represión, castigo a los vencidos y apoyos sociales al régimen franquista, 1936-1950. Granada, Universidad de Granada, 2005; GIL ANDRÉS, Carlos: Lejos del frente. La guerra civil en la Rioja Alta. Barcelona, Crítica, 2006; DEL ARCO BLANCO, Miguel Ángel: 'Hambre de siglos'. Mundo rural y apoyos sociales del franquismo en Andalucia Oriental (1936-1951). Granada, Comares, 2007.

${ }^{3}$ Por ejemplo: RODRIGO, Javier: Hasta la raiz. Violencia durante la Guerra Civil y la dictadura franquista. Madrid, Alianza, 2008; PRADA RODRÍGUEZ, Julio: La España masacrada. La represión franquista de guerra y posguerra. Madrid, Alianza Editorial, 2010; VEGA SOMBRÍA, Santiago: La Política del Miedo. El papel de la represión en el franquismo. Barcelona, Crítica, 2011; GOMEZ BRAVO, Gutmaro y MARCO CARRETERO, Jorge: La obra del miedo. Violencia y sociedad en la España franquista (1936-1950). Madrid, Península, 2011. 
taria, contribuyendo así a explicar las causas de la extrema dureza de la represión franquista, pero también otros factores como su larga duración o la implicación de no pocos sujetos en colaborar con la maquinaria represora. La represión cultural no puede ser entendida sin la existencia de una "Cultura de la Victoria" que abrazaron gran parte de los vencedores. Surgida en los días de la Guerra Civil, consagraba la existencia de, por un lado, una "verdadera España", colmada de los valores espirituales y patrióticos defendidos por los rebeldes durante la contienda; y por otro, delimitaba los límites de esa comunidad nacional, apuntando a una "anti-España", identificada con los partidarios de la II República. Fue esa cultura de no-reconciliación y de guerra sobre la que se construyó la España de los cuarenta, la España del primer franquismo, de los años de la represión de acero. Fue interiorizada por muchos vencedores. Y así, no es raro que, junto al propio lucro personal, fuese el motor explicativo de la represión socioeconómica. Sólo así se justifica cómo, tanto desde las instituciones como en las esferas más locales, los vencidos fueron lanzados contra los muros del hambre más absoluta, condenados a las largas colas de racionamiento, a alimentarse con productos de deficiente calidad, a un pequeño estraperlo por el que eran castigados, a unas condiciones laborales penosas o a ser despojados de sus empleos y bienes.

\section{La Victoria lo inunda todo: la represión cultural en la posguerra}

La experiencia de una guerra marca a todos los que participan en ella directa o indirectamente. Por tanto, parece lógico que un régimen que, como el franquista, nació y dio sus primeros pasos en medio del fragor bélico, se viera señalado con la impronta de las batallas libradas, de los sufrimientos padecidos y de los triunfos alcanzados. Menos lógico puede resultar que la profundidad de la marca bélica realizada en la piel del franquismo fuera tal, que no se borrase hasta la muerte del dictador. En efecto, el régimen de Franco no olvidaría nunca sus orígenes, puesto que en ellos descansaba su legitimidad. Las "persecuciones" sufridas durante la República y la "insostenible" situación que colocaba a España "en peligro de desintegración", transmitían la idea de que la guerra había sido no sólo inevitable sino necesaria. Con el paso de los años, la retórica de la paz formaría parte de los discursos franquistas introduciendo matices y suavizando los elementos más belicistas. Sin embargo, las apelaciones a la "Cruzada", a la Victoria, o la "nefasta" etapa republicana no desaparecieron. ${ }^{4}$

El espíritu de la victoria inundó la España de la posguerra. En todos los rincones del país se hizo sentir el triunfo obtenido por las armas de Franco en los campos de batalla. Como los propios propagandistas del régimen advertían, el 1 de abril de 1939 la guerra no terminaba, porque el enemigo seguía al acecho y había que "redimir los pecados cometidos". Era necesario mantener vivo el recuerdo de la

${ }^{4}$ AGUILAR FERNÁNDEZ, Paloma: Politicas de la memoria y memorias de la política, Madrid, Alianza, 2008, pp. 101-117. 
guerra y evitar que los españoles echaran al olvido la sangre derramada y la imagen de quiénes constituían la anti-España. ${ }^{5} \mathrm{~A}$ tal fin el franquismo se valió de un conjunto de discursos y prácticas que conformaron lo que podría denominarse como "Cultura de la Victoria".

La utilización de este término nos lleva directamente a la dificultad que plantea definir lo que se entiende por cultura. La utilidad del concepto se manifiesta al tomar una concepción abierta del mismo, interpretándolo en términos de actitudes, valores y significados compartidos que abarcarían modos de vida, lenguajes, prácticas, comportamientos, estructuras o instituciones de poder. La cultura se convierte en un campo de lucha o de negociación, donde individuos o grupos sociales tratan de interpretar y dotar de significado a la realidad que les rodea. De esta forma la cultura queda enmarcada en las relaciones de poder que se establecen entre el Estado y la sociedad. ${ }^{6}$ La irrupción de la cultura en el terreno de lo político, la sitúa entre los discursos y las prácticas producidos por el Estado y los recursos usados por la sociedad para interpretar y asignar significados a las situaciones que viven. Sin embargo, este diálogo que, a través de la cultura, se establece entre sociedad y Estado, no es algo uniforme, sino que las relaciones de poder son fluidas y cambiantes como consecuencia de las disputas y contradicciones surgidas de las luchas entre individuos y grupos sociales diversos por imponer sus propias visiones o interpretaciones de cuanto les rodea. ${ }^{7}$

Es en este sentido en el que tenemos que entender el nacimiento de la "Cultura de la Victoria". Las múltiples consecuencias del triunfo empaparon tanto los discursos emanados desde el poder y las políticas emprendidas por el "Nuevo Estado", como las maneras en que los españoles afrontaron la realidad de la posguerra y dieron significado al novedoso mundo con que se encontraron a partir del 1 de abril de 1939. En consecuencia, la "Cultura de la Victoria" fue elaborada bidireccionalmente, "desde arriba" y "desde abajo", en un proceso plagado de disputas y choques entre quienes participaron en su construcción. ${ }^{8}$ Aunque el Estado fue el director de este proceso, la colaboración de buena parte de la sociedad española fue esencial para establecer esta cultura de los vencedores de la guerra. Precisamente, la contienda librada se convertiría a lo largo de todo el régimen en el principal nexo de unión entre los muy heterogéneos apoyos con los que contó el franquismo desde sus orígenes. ${ }^{9}$ Aquellos que habían combatido por la "Causa Nacional", ya fuera en el frente o en la

${ }^{5}$ RICHARDS, Michael: "El régimen de Franco y la política de la memoria durante la guerra civil española", en ARÓSTEGUI, Julio y GODICHEAU, François (eds.). Guerra Civil. Mito y memoria. Madrid, Marcial Pons, 2006.

${ }^{6}$ ELEY, Geoff. "What is cultural history?", New German Critique, 65, 1995 p. 24

7 Véase CHARTIER, Roger: El presente del pasado. Escritura de la historia, historia de lo escrito. México, Universidad Iberoamericana, 2005, pp. 20-21; CREHAN, Kate: Gramsci, cultura y antropología. Barcelona, Bella Terra, 2004, pp. 84-86.

${ }^{8}$ Para los pugnas por dotar de contenido a la "Cultura de la Victoria" emanada desde el poder: BOX VARELA, Zira. España año cero. La construcción simbólica del franquismo, Madrid, Alianza, 2010.

${ }^{9}$ DEL ARCO BLANCO, Miguel Ángel: "The struggle continues: everyday repression and resistance in postwar francoist Spain", ponencia presentada en el Congreso: Violence and memory: considering repression and resistance in Spain, 1936-1952 in comparative perspective, Londres, 2010 p. 2. 
retaguardia, quienes habían visto sus creencias más sagradas amenazadas o los que habían sufrido en sus familias el "terror rojo", entre otros, fueron el motor que puso en movimiento la "Nueva España" nacida de las trincheras. Los damnificados de la nueva realidad, los vencidos, se vieron completamente atenazados por el control que los vencedores establecieron sobre sus conductas públicas y privadas. Obligados a desenvolverse en la posguerra, muchos derrotados acabaron por asumir su papel de "rojo" e interiorizaron los discursos ofrecidos por la interpretación franquista de la guerra que les señalaba como únicos culpables de la guerra. ${ }^{10}$

El nervio central de la "Cultura de la Victoria" fue el recuerdo del vencido. Mientras que para una parte de la sociedad el silencio de las pistolas resultó ser un alivio a los sufrimientos de tres años de dura lucha, para muchos otros ciudadanos, la paz de Franco iba a suponer el comienzo de una auténtica pesadilla. La gran mayoría de los españoles, vencedores y vencidos, hubieron de hacer frente a la difícil situación de un país destrozado por la guerra, a la carencia de los alimentos más básicos o al dolor padecido por la pérdida de algún familiar o amigo. Pero las calamidades de la posguerra fueron infinitamente más trágicas para los que habían perdido la guerra. La reconciliación no existía en el lenguaje del "nuevo" régimen y, en consecuencia, había que hacerles sentir a los enemigos su condición de vencidos. Así lo expresa A. S. R., "en mi barrio nosotros éramos rojos, y habíamos venido de Madrid como rojos. Y eso era un sello que te ponían y ya no te quitabas. Y sigue así hasta hoy en día". " El muro elevado entre los vencedores de la guerra y quienes habían resultado derrotados se extendió a lo largo de todo el periodo franquista, e incluso traspasó las fronteras temporales del régimen, dejando una herencia de valores antidemocráticos y un recuerdo negativo de la II República. ${ }^{12}$

La concepción de la Guerra Civil como "Cruzada" o "guerra contra el invasor" situó en el centro del discurso del bando nacionalista las ideas de "Catolicismo" y "Patria". La prensa, la radio o la literatura escrita fueron los instrumentos utilizados por los ideólogos franquistas para la descalificación, satanización y deshumanización del enemigo. ${ }^{13}$ Bajo el término de "anti-España" o la denominación más común de "rojos", quedaron contenidos masones, republicanos, anarquistas, separatistas, comunistas, liberales y, en definitiva, todos aquellos que obstaculizaban o se oponían a la idea de España propugnada por los sublevados. La estigmatización de los considerados como "enemigos de la Patria" lograba así un doble objetivo: la desnacio-

${ }^{10}$ FONT I AGULLÓ, Jordi. “"Nosotros no nos cuidábamos de la política'. Fuentes orales y actitudes políticas en el franquismo. El ejemplo de una zona rural, 1939-1959”, Historia Social, 49, (2004), pp. 49-66. Del mismo autor, destacan las entrevistas orales de su: ;Arriba el campo!: primer franquisme $i$ actituds polítiques en l'ámbit rural nord-catalá. Girona, Diputación de Girona, 2001.

${ }^{11}$ Entrevista realizada el 10 de marzo de 2011 a A. S. R. (Linares, 1930).

${ }^{12}$ MOLINERO, Carme: “¿Memoria de la represión o memoria del franquismo?”, en JULIÁ, Santos (coord.). Memoria de la guerra y del franquismo. Madrid, Taurus, 2006, p. 242.

${ }^{13}$ NÚÑEZ SEIXAS, Xosé M.: ¡Fuera el invasor! Nacionalismos y movilización bélica durante la guerra civil española (1936-1939). Madrid, Marcial Pons., 2006, pp. 227-261; SEVILLANO CALERO, Francisco. Rojos. La representación del enemigo en la Guerra Civil. Madrid, Alianza, 2007; GARCÍA, Hugo. "Relatos para una guerra. Terror, testimonios y literatura en la España nacional", Ayer, 76, 2009, pp. 143-176. 
nalización de quienes estaban al otro lado de las trincheras y la concesión de plena nacionalidad española a los defensores de la "Causa Nacional". ${ }^{14}$ De una parte, la idea de que los adversarios contra quienes se combatía no eran españoles sino rusos o, a lo sumo, españoles "al servicio de Moscú", transmitía al pueblo la creencia de que la independencia de España se encontraba amenazada. Las imágenes deformadas del enemigo, en las que se les presentaba como feroces bestias con cualidades animales y capaces de todo crimen o vileza, constituyeron recursos idóneos para la movilización de amplios sectores sociales en contra de quienes presuntamente trataban de deshacer España. ${ }^{15}$ De otra parte, las destrucciones de templos y de imágenes, las dificultades para practicar el culto católico o las persecuciones contra los elementos del clero, como razones fundamentales para que amplios sectores sociales encontraran razones más que suficientes para justificar la represión del régimen sobre los considerados "enemigos de Dios". ${ }^{16}$

Pero, sin duda, hay un elemento que resultó de mayor importancia aún en la movilización bélica de la sociedad española y en la justificación de la labor represiva ejercida sobre los vencidos: el "terror rojo". La narración -enormemente mitificada y, en muchas ocasiones, exagerada- de los crímenes cometidos en la retaguardia republicana, exaltó los ánimos de quienes combatían contra los "rojos" e insufló el miedo en las almas de los que permanecían en la retaguardia franquista. Aquellos que habían sido víctimas de persecuciones, perdido sus propiedades o que habían visto morir algún miembro de su familia a manos de las "hordas marxistas", establecieron vínculos de unión en torno al sufrimiento padecido, dando sentido a la guerra que se libraba y "justificando" la represión de la posguerra sobre los culpables de sus males. ${ }^{17}$ Así ocurría con un vecino de la ciudad de Guadix, José Raya Estévez, quien pedía "justicia" a las nuevas autoridades, puesto que durante la "dominación roja" de la zona, había visto su casa incendiada "por ser afecto al glorioso Movimiento Nacional", le habían desprovisto de sus tierras y los frutos de las mismas y, además, había sido encarcelado hasta la "liberación" de la población. ${ }^{18}$ "Mi abuela y mi madre -sostiene C. A. R.- decían que después de Dios, Franco. Y lo comprendo. Franco les había salvado

${ }^{14}$ Véase NÚÑEZ SEIXAS, “Del ruso virtual, al ruso real: el extranjero imaginado del nacionalismo franquista", en NÚÑ̃Z SEIXAS, Xosé Manoel y SEVILLANO CALERO, Francisco (eds.). Los enemigos de España. Imagen del otro, conflictos bélicos y disputas nacionales (siglos XVI-XX). Madrid, CEPC, 2010, pp. 233-265; Para el caso italiano: DI NUCCI, Loreto: "Lo Stato e gli italiani "antinazionali", en DI NUCCI, Loreto y GALLI DELLA LOGIA, Ernesto (coords.). Due nazioni. Leggitimazione e deleggitimazione nella storia dell'Italia contemporánea. Bolonia, Il Mulino, 2003.

${ }^{15}$ Por ejemplo: CÓRDOBA, Juan de: Estampas y reportajes de la retaguardia. Sevilla, Ediciones Españolas, 1939, p. 131 y 135-137.

${ }^{16}$ VINCENT, Mary: "The Spanish Civil War as a War of religion", en BAUMEISTER, Martin y SCHÜLER-SPRINGORUM, Stefanie (eds.), 'If you tolerate this'... The Spanish Civil war in the Age of a Total War. Frankfurt-Nueva York, Campus Verlag, 2008, pp. 74-89.

${ }^{17}$ ANDERSON, Peter y DEL ARCO BLANCO, Miguel Ángel: "Construyendo el franquismo: violencia y represión en el campo andaluz de posguerra”, en Ayeres en discusión: temas claves de la Historia Contemporánea hoy. Murcia, Servicio de Publicaciones de la Universidad, 2008.

${ }^{18}$ Archivo de la Diputación Provincial de Granada, Caja 130, pieza 23. 
la vida. Se habían pasado noches enteras en lo alto de un tejado, agarradas a una chimenea, esperando que no las encontraran, porque si las encontraban las mataban". ${ }^{19}$

La humillación sistemática de los vencidos nació durante los años de confrontación bélica, pero sería con el cese de las hostilidades cuando se desarrollase en toda su plenitud. De hecho, a la altura de septiembre de 1938, de acuerdo con la opinión del embajador italiano en España, la población española sólo deseaba el final de la guerra, porque no veía más razones para combatir. ${ }^{20}$ Pero la llegada de la victoria, hizo que una importante parte de la sociedad española fuera aceptando la visión franquista de los hechos. Con el paso de los años, una mayoría de los ciudadanos había interiorizado la idea de que la II República había sido un periodo negativo de la historia de España, causante de muchos de los enfrentamientos que habían originado la Guerra Civil. Al mismo tiempo, la contraposición de la convulsa etapa republicana con la paz obtenida gracias a la guerra, hizo que Franco apareciese como el guardián de la misma y el garante de que España viviera en la "normalidad". ${ }^{21} \mathrm{Si}$ a ello añadimos que los "enemigos de España" fueron señalados como responsables de la situación de escasez y miseria de la posguerra, como culpables de los ataques de las potencias extranjeras hacia el país, o como perturbadores de la "paz social" reinante mediante la actividad guerrillera o la participación en el estraperlo, parecía justificada la persecución, hasta su completa desaparición, de quienes se oponían al "Nuevo Estado".

La creación de la "nueva" España conllevó la eliminación física de muchos individuos, la depuración de las instituciones y los organismos del Estado, el encarcelamiento de aquellos elementos considerados "peligrosos" o "desafectos" al gobierno nacional o su empleo en trabajos forzados para que pudieran redimirse del daño que supuestamente habían ocasionado a su Patria. ${ }^{22}$ Pero, paralelamente, se desarrolló toda una labor de reespañolización y recatolización destinada a implantar en la España de la posguerra de ideas fundamentales para el "Nuevo Estado" y a eliminar de raíz cualquier vestigio de carácter democrático o republicano. Por supuesto, este proceso estuvo en buena medida impulsado por las autoridades franquistas que desarrollaron una legislación y una propaganda destinada a conseguir que la mayoría de los españoles se identificara con los principios que defendían y a que los vencidos en la guerra también quedasen derrotados en la paz. Pero fue en el marco de lo local, en las ciudades y en los pueblos de España, donde se pusieron las mimbres necesarias para que la "Cultura de la Victoria" aplastara a los perdedores de la guerra, pues fue allí donde se produjo el contacto más directo entre el pueblo y las instituciones del régimen.

\footnotetext{
${ }^{19}$ Entrevista realizada el 14 de junio de 2011 a C. A. R. (Jaén, 1943).

20 "Situazione político-militare spagnola", Archivio Storico Diplomatico del Ministero degli Affari Esteri, busta 1216.

${ }^{21}$ CAZORLA SÁNCHEZ, Antonio: Fear and progress. Ordinary Lives in Franco's Spain, Oxford, Wiley-Blackwell, 2010, p. 18-21.

22 JULIÁ, Santos (coord.): Victimas de la Guerra Civil. Madrid, Temas de Hoy, 1999; GÓMEZ BRAVO, Gutmaro: El exilio interior. Cárcel y represión en la España franquista, 1939-1950, Madrid, Taurus, 2009, pp. 45-46.
} 
Uno de los ámbitos donde más evidente resultó la represión cultural de los vencidos fue en la esfera pública. Las calles y las plazas de las ciudades y pueblos de España fueron el escenario escogido por el régimen franquista para mostrar la "flamante" nación nacida de la victoria. Cada desfile militar, ceremonia o celebración patriótica o religiosa constituía una demostración de fuerza por parte del Estado con la que intentaba transmitir a los ciudadanos en qué debían creer. Durante la guerra, las movilizaciones públicas -entierros, procesiones religiosas, manifestaciones o desfiles militares- contribuyeron a la construcción social del enfrentamiento, ritualizando el espacio público mediante el uso de los símbolos del "Nuevo Estado". Tras la misma, la proliferación de cruces, imágenes religiosas, banderas rojigualdas o emblemas con el yugo y las flechas de Falange a lo largo de todo el marco urbano confirmó la hegemonía simbólica del franquismo sobre el conjunto de ciudades y pueblos de España. Los vencidos se veían avocados a aceptar los símbolos del nuevo régimen como los propios de la nación española y a admitir el carácter antiespañol de los defendidos por ellos. ${ }^{23}$

El diseño de un calendario festivo sirvió para indicarle a la población los ritmos de su vida cotidiana, los actos que debían celebrar o si tenían que cerrar su comercio para vitorear al Caudillo a su paso por la localidad. ${ }^{24}$ La supresión de las fiestas republicanas y la adecuación de las nuevas festividades a los postulados del régimen buscaban la invisibilidad de los "rojos" que, como enemigos del franquismo, tenían negada su pertenencia a la comunidad de los vencedores. Algunas conmemoraciones -como la celebración del 18 de julio o el "Día de la Victoria" - subrayaban especialmente la división entre vencedores y vencidos. Incluso en las décadas de los 50 y 60 , cuando los resultados de la victoria eran considerados "un fruto que pertenecía a todos los españoles", los editoriales de los periódicos españoles destacaban cómo "la guerra fue una necesidad histórica insoslayable y necesaria" que llevó a una victoria cuyo legado debía ser "la fidelidad a nuestros muertos" y se lamentaban de la "poca importancia que los españoles dan a la paz", puesto que no pensaban "en lo mucho que había costado conseguirla". ${ }^{25}$ En resumen, la cohesión que el régimen lograba entre sus apoyos sociales en estas conmemoraciones, mediante la inauguración de obras, la entrega de viviendas, los ritos multitudinarios o las pagas extraordinarias a los obreros, era directamente proporcional a la humillación y la exclusión sentida por los perdedores de la guerra.

Sin salir del mapa urbano, el símbolo que mejor encarnó la división existente entre vencedores y vencidos fueron los monumentos a los caídos. Ya durante la Guerra Civil pero, especialmente, al término de la misma, en las ciudades y pueblos de España se fueron creando "lugares de memoria" en recuerdo de "quienes habían dado su vida

${ }^{23}$ CRUZ MARTÍNEZ, Rafael: "Old symbols, new meanings: mobilising the rebellion in the summer of 1936", en RICHARDS, Michael y EALHAM, Chris (eds.). The Splintering of Spain: Cultural History and the Spanish Civil War, 1936-1939. Nueva York, Cambridge University Press, 200, pp. 159-176.

${ }^{24}$ Véase CENARRO LAGUNAS, Ángela: “Los días de la 'Nueva España': entre la 'revolución nacional' y el peso de la tradición”, Ayer, 51, (2003), pp. 115-134.

${ }^{25}$ Ideal, 1-4-1956; Patria, 1-4-1966 y 1-4-1967. 
por la Patria". A semejanza de los monumentos erigidos en Europa tras la I Guerra Mundial, los realizados en la España de los cuarenta, buscaban perpetuar el recuerdo de los "mártires" y "caídos" por la Patria y crear "lugares de duelo" en torno a los cuales el pueblo pudiera manifestar su dolor. ${ }^{26}$ Pero en el caso español el recuerdo de quienes habían muerto, no constituía el motivo en torno al cual fortalecer los lazos de la comunidad nacional y reagrupar a la totalidad de la nación para reemprender la marca en un país en ruinas. Al contrario, los monumentos erigidos en España tras la guerra perpetuaron el recuerdo de los caídos de un solo bando, convirtiéndose en ejemplo para que las generaciones futuras no olvidaran los sacrificios de la "Cruzada" y los símbolos de la victoria que hacían más profunda la humillación de los vencidos, al no ver estos reconocido el recuerdo de sus familiares muertos.

Como en otros muchos ámbitos, fue el Estado franquista quien capitaneó la construcción de los monumentos a los caídos. Por ello, no dudó en tratar de imponer una unidad de criterios artísticos y estéticos para la edificación de las construcciones, indicando a las autoridades locales qué elementos debían tener presencia en los mismos y cuáles no. ${ }^{27}$ Pero, como en otros aspectos que conformaron esta cultura victoriosa, la construcción de las cruces de los caídos también fue implementada "desde abajo". Al fin y al cabo, era el pueblo el que tenía la necesidad de expresar el trauma vivido durante la guerra y de sentirse partícipe de la confección de estos "lugares de memoria" en honor de sus familiares o vecinos fallecidos. ${ }^{28} \mathrm{~A}$ tal efecto, en muchas ciudades y pueblos "liberados" se abrieron, todavía en los años de guerra, suscripciones destinadas a subvencionar los costes de construcción de cruces, lápidas o conjuntos escultóricos que homenajearan a "sus caídos". En Igea (La Rioja) el Ayuntamiento abrió una "suscripción voluntaria" entre los vecinos para sufragar la construcción de una "Cruz de los Caídos" como símbolo del nuevo régimen y expresión de violencia simbólica hacia los vencidos. ${ }^{29}$ Antiguos excombatientes, instituciones del régimen, pequeñas empresas privadas o individuos corrientes fueron muchas veces los motores de tales iniciativas constructivas, que consideraban un acto de justicia por los sufrimientos padecidos. Este es el caso de una mujer que, bajo el nombre de "Pilar de Aragón”, dirigió a Ramón Serrano Súñer una carta en 1938, pidiéndole que se

${ }^{26}$ BARTOV, Omer: Mirrors of Destruction. War, Genocide and Modern Identity. Nueva York, Oxford University Press, 2000, p. 48; WINTER, Jay: Sites of Memory, Sites of Mourning: The Great War in European Cultural History. Londres, Cambridge University Press, 1995, pp. 51-53.

${ }^{27}$ Véanse LLORENTE HERNÁNDEZ, Ángel: "La propaganda por la imagen y el arte en la posguerra. La Comisión de Estilo en las conmemoraciones de la Patria y el Departamento de Plástica entre 1939 y 1945", en TUSELL, Javier et al. (eds.). El régimen de Franco, 1936-1975: política y relaciones exteriores. Madrid, UNED, 1993; y DEL ARCO BLANCO, Miguel Ángel: "Sangre y cruces: monumentos conmemorativos de la Guerra Civil Española (1936-1945)", VII Encuentro de Investigadores del franquismo, Santiago de Compostela, 2009.

${ }^{28}$ Así había ocurrido en Europa tras la Gran Guerra: WINTER, Jay: "Remembrance and Redemption: a Social interpretation of War Memorials", Harvard Design Magazine, otoño, (1999), pp. 71.77; MOSSE, George L.: Fallen soldiers: reshaping the memory of the World Wars. Nueva York, Oxford University Press, p. 90.

${ }^{29}$ En la también riojana localidad de Haro se abrió una "suscripción entre el vecindario, por desear la generalidad del mismo, el cooperar con sus entregas a la ejecución de este proyecto": AGA, Cultura, $21 / 5372$. 
erigiera una monumento en su pueblo y rogándole "que en todos los pueblos de España que tengan hijos, mártires o héroes a quien honrar, no falte la Cruz con los nombres de los Caídos" . ${ }^{30}$ Una vez construido el monumento, los familiares de los caídos del bando franquista tuvieron un lugar donde honrar a sus fallecidos. Para los hijos y viudas de los "rojos" sólo quedaba el rechazo por parte de la "comunidad de los vencedores", encarnado en cruces y lápidas situados en los lugares centrales de pueblos y ciudades, donde todo el mundo pudiese verlos.

El elemento religioso resultó igualmente crucial en la represión cultural de los perdedores de la guerra. La concepción de la guerra como "Cruzada religiosa" sacralizó la contienda e hizo que ésta fuera considerada como una consecuencia de la descristianización religiosa. ${ }^{31}$ El "pecado colectivo" cometido por todos los españoles, debía ser lavado en una guerra purificadora, mediante el derramamiento de sangre. Llegada la paz, se abriría un necesario periodo de penitencia y expiación de los pecados que convirtió a España en un "inmenso purgatorio". Esta retórica de redención de los pecados tendría sus consecuencias prácticas en la proliferación de los actos de comunión masiva, la participación del pueblo en misiones religiosas o la multiplicación de la asistencia a misa de españoles verdaderamente convencidos de sus ofensas a la religión católica o necesitados de un sostén espiritual que les ayudase a superar las calamidades de la guerra y a soportar la dureza de la posguerra.

Por una paradójica coincidencia, la victoria definitiva sobre la II República se produjo al inicio de la Semana Santa de 1939, posibilitando al régimen su uso propagandístico. En efecto, las comparaciones entre el "calvario" sufrido por Cristo y por España, los actos de contrición desarrollados y la realización de penitencias por los pecados cometidos se sucedieron durante estos meses. El espacio urbano se pobló de misas de campaña, actos de desagravio, procesiones y manifestaciones externas de arrepentimiento por las "ofensas" cometidas contra Dios y contra la Iglesia. De este modo, fue frecuente la presencia de hombres y mujeres desfilando en procesiones religiosas, descalzos, con cadenas o encapuchados para "lavar sus culpas". La reconstrucción de iglesias, las reposiciones de hornacinas y cruces derribadas o la reparación de las imágenes religiosas destruidas desde 1931, formaron parte del proceso de resacralización del espacio urbano y eliminación simbólica de lo republicano. En consecuencia, las ceremonias religiosas fueron completamente politizadas, procurando eliminar las interpretaciones populares de procesiones o actos católicos tradicionales. La celebración en algunas ciudades de exposiciones de esculturas religiosas mutiladas en zonas céntricas de las mismas, buscaba impresionar a la población al mostrarle el grado de crueldad con que se había empleado el enemigo. Más significativa resultó la restauración de la Cruz de la Rauda, situada en pleno corazón del barrio obrero del Albayzín en Granada. La reconstrucción de la misma había sido realizada por "los mismos que la habían destrozado" y, por ello, el Delegado de Bellas Artes, Fidel Fernández, no dudaba en pedir el perdón de quienes consideraba "redimidos". ${ }^{32}$ En

\footnotetext{
${ }^{30}$ AGA, Cultura, 21/2382.

${ }^{31}$ RICHARDS, Michael: A Time of Silence. Civil War and the Culture of Repression in Franco's Spain, 1936-1945. Cambridge, Cambridge University Press, 1998.

${ }^{32}$ HERNÁNDEZ BURGOS, Claudio: Granada azul. La construcción de la "Cultura de la Victoria" en el primer franquismo, 1936-1951, Granada, Comares, 2011, capítulo 6.
} 
esta misma línea, el paso de procesiones de Semana Santa por los barrios obreros de Málaga o la labor "recatolizadora" emprendida en estos mismos núcleos por el arzobispo de la ciudad, Balbino Santos Olivera, ${ }^{33}$ constituyeron actuaciones significativas mediante las cuales la "Cultura de la Victoria" fue tomando el control de las ciudades y obligándole a los vencidos de la guerra a aceptar los principios ideológicos que regían la "Nueva España".

La "Cultura de la Victoria" tuvo en la represión de la moralidad uno de los pilares fundamentales para condicionar las actitudes políticas. La fiscalización de las conductas de los ciudadanos permitió al franquismo llegar hasta el último rincón de cada casa y, en cierto modo, muchos españoles pudieron aceptar algunos aspectos de este control estatal, marcados por el trauma bélico y deseosos de volver a la normalidad. ${ }^{34}$ Elementos como el papel que le correspondía a cada miembro de la familia, los rasgos que debían caracterizar el hogar español o las normas sexuales y la moralidad del ámbito privado no escaparon al alcance del "Nuevo Estado". El régimen de Franco situó al conjunto de la sociedad española bajo una estrecha vigilancia con el objetivo de imposibilitar "comportamientos desviados" por parte de la ciudadanía. A tal efecto, señaló a los españoles que conducta era la adecuada para cada situación, dictó normas referentes a la vestimenta en lugares públicos como las piscinas o las playas y controló inflexiblemente cuanto sucedía en lugares potencialmente "inmorales" como las salas de cine. De esta manera, el franquismo estigmatizaba a la II República al presentarla como origen de toda inmoralidad y de todas las actitudes "antiespañolas".

Los comportamientos considerados inmorales hundían sus raíces en la misma deshumanización y satanización a la que los "rojos" habían sido sometidos durante la guerra. Eran especialmente las mujeres quienes resultaban paradigmáticas por su inmoralidad. Durante la Guerra Civil, la literatura franquista destacó a las "rojas" por su crueldad y sus comportamientos "poco femeninos". ${ }^{35}$ Mientras el franquismo ofrecía un modelo alternativo de mujer, las "rojas" iban a ser despiadadamente castigadas. Para el "Nuevo Estado" no era suficiente penitencia que hubieran perdido su marido o sus hijos o que le hubieran sido requisados todos sus bienes quedando sin medio alguno para ganarse la vida. Era necesario hacerles sentir todo el peso de la victoria; por ello, muchas fueron obligadas a beber aceite de ricino o paseadas en ropa interior con la cabeza afeitada entre sus vecinos. ${ }^{36} \mathrm{Y}$ tras la humillación llegaba

${ }^{33}$ RICHARDS, Michael: "Morality and biology in the Spanish Civil War: psychiatrists, revolution and women prisoners in Málaga", Contemporary European History, 10, 2001 pp. 407-409; ALFONSÍ, Adela: "La recatolización de los obreros en Málaga, 1937-1966. El nacional-catolicismo de los obispos Santos Olivera y Herrera Oria", Historia Social, 35, (1999), pp. 119-123.

${ }^{34}$ Véase GELLATELY, Robert: No sólo Hitler. La Alemania Nazi entre la coacción y el consenso. Barcelona, Crítica, 2002; JUDT, Tony: Postguerra. Una historia de Europa desde 1945. Madrid, Taurus, 2006, pp. 35-69.

${ }^{35}$ Por ejemplo: las mujeres madrileñas habrían pedido la cabeza del general López Ochoa para "enviarla salda a Asturias y que la vean los mineros a los que persiguió", citado en FERNÁNDEZ ARIAS, Adelardo: Madrid bajo el terror: Impresiones de un evadido que estuvo a punto de ser fusilado. Zaragoza, Librería General, 1937, p. 60.

${ }^{36}$ GONZẢLEZ DURO, Enrique: El miedo en la posguerra. Franco y la Espada derrotada: 
el miedo, que podía convertirse en un arma potencialmente peligrosa en manos de alguien que buscara aprovecharse de la indefensión de una "roja". Así ocurría el 22 de agosto de 1936 en la ciudad de Granada, cuando Francisco García Romero se presentaba en la casa de Vicenta Remacho Jiménez y, haciéndose pasar por policía, le dijo que "ella y toda su familia eran rojos" y le amenazó con denunciarla "en caso de que no cohabitase con él". El intento de violación, "impedido por sus familiares presentes en la casa" y la suplantación de autoridad, se saldó con una escueta pena de poco más de cuatro meses de cárcel. ${ }^{37}$

Igualmente, espacios públicos y privados fueron férreamente controlados con el objetivo de evitar "actitudes antiespañolas". Durante la Guerra Civil y la posguerra el Estado franquista hizo de España una sociedad "autovigilada", donde cada individuo tenía la obligación de denunciar cuantas actitudes o comentarios pudieran socavar la legitimidad del régimen o desprestigiar algún aspecto de su política. Por supuesto, la efectividad de tales prácticas delatoras dependía bastante de la cobertura que el Estado daba a las mismas, y el régimen de Franco hizo mucho por alentarlas. Pero, al mismo tiempo, muchas de estas denuncias fueron -como en otras dictaduras europeas- realizadas por individuos corrientes movidos por motivaciones patrióticas, económicas o personales ${ }^{38}$ Los españoles de la posguerra -especialmente aquellos con antecedentes "desfavorables"- debían abstenerse de criticar al Jefe de Estado, hacer "comentarios derrotistas", mostrar su simpatía por los "rojos" o criticar la situación política y económica existente. Así ocurrió con Juan Sánchez Maldonado, antiguo alcalde republicano de una pedanía almeriense de Adra, quien manifestó públicamente que la II Guerra Mundial sería favorable a los "rojos" y "que después estos vendrían a España". Uno de sus vecinos acudió rápidamente a denunciar el hecho ante la Guardia Civil. A las pocas horas era detenido y puesto en manos de la justicia militar. Más impactante es la historia de Carmen García Puga, una anciana de la localidad granadina de Iznalloz cuyo marido había muerto en prisión y a quien su condición de vencida le había costado la pensión de viudedad. Una noche de junio de 1940, probablemente animada por el alcohol, afirmó en una de las tabernas del pueblo que "¡Si Franco nos da algo, es bastante por culo!". Un par de vecinos que presenciaba la escena no dudaron en denunciarla, provocando su arresto y su posterior condena a más de dos años de cárcel. ${ }^{39}$ La colaboración de la población española

la politica del exterminio. Madrid, Oberón, 2003, Capítulo 7; FRASER, Ronald: Recuérdalo tú y recuérdalo a otros. Historia oral de la guerra civil española. Barcelona, Crítica, 1979, Vol. 1., pp. 377-378; Resulta de gran interés la investigación llevada a cabo por Irene Abad, Iván Heredia y Sescún Marías, expuesta en "«Represión sexuada», un estudio cultural de la violencia franquista sobre las mujeres republicanas. España, 1936-1952", ponencia presentada en la 42nd Annual Conference of the Association of Spanish and Portuguese Historical Studies, Lisboa, junio-julio, 2011.

${ }_{37}$ Archivo de la Real Chancillería de Granada, Audiencia Provincial, Sección Criminal, Libro 1096, Sentencia 26.

${ }^{38}$ FITZPATRICK, Sheila y GELLATELY, Robert: "Introduction to the practices of denunciation in Modern European History", The Journal of Modern History, (1996), 98, 747-767.

${ }^{39}$ Los casos están recogidos en RODRÍGUEZ BARREIRA, Óscar: "«Cuando lleguen los amigos de Negrín...» Actitudes individuales y opinión pública ante la II Guerra Mundial en una provincia del Sur. Almería, 1939-1945”, Historia y Política. Ideas, procesos y movimientos sociales, 
en la delación de sus vecinos en cualquier aspecto de la vida cotidiana se sustentó en la idea interiorizada por muchos españoles según la cual los "enemigos" de la nación debían ser castigados como "compensación" por los sufrimientos anteriormente padecidos. Si la "justicia de Franco" no se mostraba todo lo implacable que debiera, eran los vencedores los primeros que manifestaban sus quejas. Según un informe de la Falange granadina, en noviembre de 1940 existía "un gran descontento" en la cercana localidad de Maracena por la libertad concedida a Francisco Pérez García, un antiguo militante de la CNT que supuestamente había pertenecido a bandas armadas y "propugnado el asesinado de personas de orden". Eran los propios vecinos los que demandaban un "justo" castigo y criticaban la benevolencia de las autoridades..$^{40}$

En cada esquina de la España de Franco, la victoria acechaba al vencido. En las calles, los símbolos de la "Nueva España", las placas que dedicaban una calle a "héroes" de la "Cruzada", o los monumentos a los caídos, recordaban diariamente a los derrotados en la contienda el papel que les correspondían en la dura posguerra. Pero a ello también contribuían las miradas de los vecinos, los dedos acusadores que recordaban su condición de "rojo" a quienes habían perdido la guerra, o el agudo oído de algún conciudadano deseoso de limpiar el país de los "enemigos de España". Humillados, rechazados, estigmatizados y derrotados, la "Cultura de la Victoria" grabó indeleblemente el sello de "rojo" sobre la piel de los vencidos.

\section{Acorralados: la represión socioeconómica en el primer franquismo}

Existe algo paradójico con la represión socioeconómica en la España del primer franquismo. Pese a acontecer en un momento histórico de extrema dureza material, el de una posguerra, suele ser incluida tan sólo de forma tangencial o secundaria en las monografías globales sobre la represión franquista. ${ }^{41}$ A nuestro juicio, no fue así. Lo que sucedió en la España de los cuarenta en la extensa esfera de lo social no puede desligarse en áreas asépticas e incomunicadas. La represión física de aquellos años no puede quedar desvinculada de la Cultura de la Victoria, analizada en el primer epígrafe de este trabajo, pero tampoco de la represión socioeconómica. Las tres compartieron motivaciones y, en ocasiones, actores y víctimas.

La represión socioeconómica es difícil de definir. No es una represión explícita como, por ejemplo, la llevada a cabo en los consejos de guerra. También en ella hay jueces, hay abogados y hay reos, por supuesto. Pero parte de ella se desarrolla fuera de las salas de juicios: muchas veces ocurre en cualquier lugar, con actores difumi-

18, (2007), p. 301; y GÓMEZ BRAVO, Gutmaro y MARCO CARRETERO, Jorge: La obra del miedo... Op. Cit., pp. 27-29.

${ }^{40}$ AGA, Presidencia, Caja 52/02974.

${ }^{41}$ JULIÁ, Santos (coord.): Victimas de la Guerra Civil... Op. Cit; RODRIGO, Javier: Hasta la raíz... Op. Cit.; PRESTON, Paul: El holocausto español. Odio y exterminio en la Guerra Civil y después. Barcelona, Debate, 2011; GÓMEZ BRAVO, Gutmaro y MARCO CARRETERO, Jorge: La obra del miedo... Op. Cit. Dos recientes excepciones: PRADA RODRÍGUEZ, Julio: La España masacrada... Op. Cit.; VEGA SOMBRÍA, Santiago: La Politica del Miedo...Op. Cit. 
nados, así como sus acusaciones y actuaciones ante los inculpados. Además de los tribunales constituidos por el régimen para asegurar la derrota económica y social de los vencidos, es una represión que puede comenzar en cada relación económica cotidiana, en la mera compra-venta de un producto o en su comercialización o fabricación, pero que también se extiende al mundo de las cartillas de racionamiento, al del trabajo y el empleo, y a otras formas tan explícitas como la incautación de bienes por motivos políticos. En todo caso, esta represión socioeconómica hubiese sido inexistente o, por lo menos, más limitada si, por un lado, la sociedad quebrada del primer franquismo no se hubiese bañado en la "Cultura de la Victoria" y, por otro, la autarquía no hubiese sido implantada en la España de posguerra. Esto nos hace sostener que no fue casual y que, si bien no fue planeada de manera fría desde las altas esferas, sí fue consecuente con el contexto cultural, social y político sobre el que se construyó el "Nuevo Estado". ${ }^{2}$

En este sentido, para comprender la naturaleza de la represión socioeconómica, debemos vincular lo político con lo económico. La acción de los ciudadanos comunes o las instituciones franquistas contra los vencidos no sólo estuvieron guiadas por motivos políticos, sintetizados en la cultura triunfalista y revanchista de aquellos días, sino también por causas económicas: la satisfacción de los intereses de las bases sociales del régimen. Así, la represión socioeconómica no puede entenderse sólo en una dirección, esto es, como una fuerza incontenible y severa contra las vidas de los vencidos y sus familias; también fue algo que tuvo consecuencias en el destino de aquellos que habían ganado la guerra, otorgándoles una posición de privilegio para enriquecerse o más acomodada frente a la impresionante dureza de aquellos años. Tampoco la represión socioeconómica puede ser concebida como algo sólo impuesto desde arriba: por abajo, tanto sus ejecutores como sus víctimas tomaron una actitud determinada hacia ella. Los primeros pudieron tomar más o menos partido en la misma, obteniendo variados beneficios; pero las víctimas también reaccionaron ante ella, y en muchos casos se decidieron a transgredir la ley y el orden impuesto, luchando por su supervivencia y haciendo de su actitud una verdadera forma de resistencia. ${ }^{43}$

Es difícil trazar una línea que delimite quiénes eran víctimas y verdugos en la represión socioeconómica. Fue una represión cambiante, determinada por las rela-

${ }^{42}$ Unas interesantes reflexiones sobre la "intención" y las "estructuras" en el régimen nazi: KERSHAW, Ian: The nazi dictatorship. Problems and perspectives of interpretation. London, Edward Arnold, 1985, p. 80 y ss. A nuestro juicio, es esta afirmación que vertimos en el texto lo que se deduce de la obra de Michael RICHARDS (A Time of Silence... Op. Cit..) y no que la autarquía fuese diseñada de modo aséptico desde las alturas para liquidar a los vencidos. Ver: MOLINERO, Carme e YSAS Pere: "El malestar popular por las condiciones de vida. ¿Un problema político para el régimen franquista?", Ayer, 52 (2003), pp. 255-280.

${ }^{43}$ Por motivos de espacio, dejamos de lado en este artículo las "resistencias cotidianas" al régimen franquista. En los últimos años han recibido una amplia atención por la historiografía: RODRÍGUEZ BARREIRA, Óscar J.: Migas con miedo. Prácticas de resistencia en el primer franquismo. Almería 1939-1952. Almería, Universidad de Almería, 2008; DEL ARCO BLANCO, Miguel Ángel: 'Hambre de siglos'... Op. Cit. La estrecha vinculación de este tipo de resistencias con otras más abiertas: RICHARDS, Michael: "Falange, Autarky and crisis: The Barcelona General Strike of 1951", European History Quarterly, 29, 4 (1999), pp. 543-585. 
ciones económicas y políticas de cada momento y en la que no sólo participaron los vencedores y fueron víctima los vencidos. Al igual que en el caso de la represión física durante la guerra y la posguerra, la represión socioeconómica estuvo repleta de zonas grises ${ }^{44}$ En aquel mundo de miseria y de estraperlo, donde el hambre ponía en peligro y atenazaba las vidas de los más humildes, la supervivencia se convirtió en la máxima. Ante la escasez de los recursos, ante la necesidad de reunir el suficiente alimento para salir adelante, muchos hombres y mujeres cruzaron la legalidad y se implicaron de forma indirecta con la represión. Robos, falsificaciones de las cartillas de racionamiento, ventas de estraperlo y las más ingeniosas fórmulas se acabaron convirtiendo, además de en una vía de escape para algunos, en perjuicio para otros.

Estas reflexiones sobre la represión socioeconómica del primer franquismo se evidencian, a nuestro juicio, en las variadas y cambiantes formas que ésta adoptó en aquellos años. Dedicamos las siguientes páginas a analizarlas.

Si hubo una esfera en torno a la que giró la represión socioeconómica, ésta fue la del hambre. La miseria de los más humildes y, sobre todo, la gestión que de la misma hicieron las autoridades y bases sociales del régimen, se convirtió así en un elemento clave para explicar la consolidación y estabilidad del franquismo. ${ }^{45} \mathrm{Y}$ es en ese contexto en el que el modelo económico autárquico debe ser entendido: un sistema económico que entregaba a un Estado autoritario (que hacía bandera de la victoria y de la no-reconciliación tras una guerra civil), los resortes imprescindibles para guiar la vida económica y el sustento de los ciudadanos. El mejor ejemplo de todo ello fue, sin duda, el sistema de racionamiento. Curiosamente, el régimen de racionamiento fue establecido en todo el territorio nacional poco después del fin de la guerra civil, y se mantendría hasta $1952 .{ }^{46}$ Con una organización cambiante, en definitiva hacía depender el sustento de individuos y familias de una cartilla algo amarillenta, presidida por el escudo franquista y los lemas del "Nuevo Estado". Gran parte de los alimentos de primera necesidad quedaron intervenidos por diversas instituciones, quienes se encargarían de suministrarlas a la población. Fueron las autoridades nacionales y provinciales de la Comisaría de Abastecimientos y Transportes las que determinaron las cantidades a repartir en cada lugar y momento. Tomaron así decisiones claves para condicionar la estabilidad del régimen. De este modo, las ciudades recibieron siempre un suministro alimenticio mayor, con el fin de contener posibles brotes de conflictividad. Fue el caso de la provincia de Jaén en 1945, donde en la capital fueron distribuidos hasta 15 artículos diversos, mientras que en las zonas rurales lo fueron sólo 6 alimentos básicos; la diferencia calórica entre el suministro de las ciudades y los pueblos superó las 1.100 kilocalorías. ${ }^{47}$ Pero a veces, ni las raciones fijadas eran distribuidas realmente. Un informe de la diplomacia británica referido a la provincia

${ }^{44}$ GIL ANDRÉS, Carlos: "La zona gris de la España azul. La violencia de los sublevados en la Guerra Civil”, Ayer, 76 (2009), pp. 115-141.

${ }^{45}$ DEL ARCO BLANCO, Miguel Ángel: "Hunger and the consolidation of the Francoist Regime (1939-1951)", European History Quarterly, 40, 3 (2010), pp. 458-483.

${ }^{46}$ Orden Ministerial de 14 de mayo de 1939 (BOE 17/5/1939).

${ }^{47}$ AGA, Presidencia del Gobierno. Partes mensuales de enero, abril, junio, septiembre y diciembre de 1945. Caja 20672. 
de Huelva, evidenciaba una diferencia de más del 77 por 100 entre el racionamiento oficial de pan y el realmente distribuido. ${ }^{48}$ ¿Dónde iban a parar esos productos? Las autoridades locales franquistas, verdadera espina dorsal del nuevo régimen, eran las encargadas de regular el abastecimiento, destinando esos productos para la mejor alimentación de los suyos o para obtener pingües beneficios con la venta de esos artículos en el mercado negro. El beneficio de los afectos al régimen era directamente proporcional a las deficiencias alimentarias de los vencidos. ${ }^{49}$

Existían múltiples mecanismos para beneficiar a los cercanos al régimen mientras que se castigaba con el hambre y el silencio a los desafectos. Uno de los más populares era duplicar o falsificar las cartillas de racionamiento para acceder a más productos de primera necesidad. Por ejemplo, en 1944 se detectaron en la ciudad de Alicante 3.306 cartillas de racionamiento ilegales. De ellas, casi el 18 por 100 pertenecían a soldados en servicio activo; como es sabido, el Ejército era uno de los pilares del régimen. ${ }^{50}$

Los efectos represivos del sistema de racionamiento saltan todavía más a la vista cuando acercamos la lente a la realidad cotidiana. Era común que los ciudadanos fuesen inscritos en los censos de racionamiento en función de su capacidad económica. Así, sus cartillas podrían ser de primera, segunda o tercera categoría. La pertenencia a esta última garantizaba un mayor acceso a productos a precio oficial de tasa, mucho más barato que el que podían alcanzar los artículos en el mercado negro. También en este aspecto las autoridades del régimen maniobraron guiadas por el favoritismo y la discrecionalidad hacia sus afectos. Una nota de prensa en un periódico de aquellos años reconocía que tras revisar la clasificación de las cartillas de racionamiento de Madrid, "se da el sorprendente resultado de que solamente aparecen inscritos en la $1^{\text {a }}$ y $2^{\text {a }}$ categoría un número muy escaso de personas". ¿No había ni ricos ni clases medias en la capital del país? Curiosamente éstas eran precisamente las bases sociales más firmes del "Nuevo Estado". ${ }^{51}$ Como afirmaba con ironía Rafael Abellá años atrás, "casi toda España se había apuntado a pobre". ${ }^{2}$

La sociedad española de posguerra estaba, en el mundo de los hechos, dividida en dos grupos. En primer lugar, aquellos que pudieron conseguir productos de calidad y en relativa abundancia, bien porque disponían del acceso a ellos al ser productores

${ }^{48}$ The National Archives (TNA), PRO, FO 371/24509. Informe sobre suministro de alimentos en España. 19-11-1940.

${ }^{49}$ DEL ARCO BLANCO, Miguel Ángel: 'Hambre de siglos'..., pp. 282-287.

${ }^{50}$ MORENO FONSERET, Roque: "Movimientos interiores y racionamiento alimenticio en la postguerra española", Investigaciones Geográficas, 11 (1993), p. 312.

${ }^{51}$ Son numerosos los estudios al respecto, predominando sobre todo los análisis regionales o locales. Para Andalucía: COBO ROMERO, Francisco y ORTEGA LÓPEZ, Teresa: "No sólo Franco. La heterogeneidad de los apoyos sociales al régimen franquista y la composición de los poderes locales. Andalucía, 1936-1948”, Historia Social, 51 (2005), pp. 49-71. Una visión general, para el mundo rural: DEL ARCO BLANCO, Miguel Ángel y GÓMEZ OLIVER, Miguel: "Los franquistas del campo. Los apoyos sociales rurales del régimen de Franco (1936-1951)", en ORTEGA LOPEZ, Teresa María y COBO ROMERO Francisco (eds.): La España rural (Siglos XIX y XX). Granada, Comares, 2011.

52 ABELLÁ, Rafael: Por el Imperio hacia Dios. Crónica de una Posguerra (1939-1955). Barcelona, Planeta, 1978, p. 84. 
de los mismos, o porque por su posición más o menos acomodada podían pagar su precio en el mercado negro. Eran los hombres del pan blanco. Y en segundo lugar, los que por su posición humilde, su única vía de abastecimiento era el racionamiento. A estos últimos pertenecían las clases más bajas, muchas de las cuales se habían comprometido o simpatizado con sindicatos o partidos de izquierda durante la II República. Eran los hombres del pan negro. Y fueron ellos los que estuvieron a merced del sistema de racionamiento, cuyas características más evidentes eran la escasez de los productos suministrados, su poca variedad y su pésima calidad. Y fueron ellos los que sufrieron las consecuencias de un sistema que era a la vez su salvación frente a la inanición, pero también la prueba evidente de una represión cotidiana en el plano de los hechos. Estas reflexiones parecían estar en la mente del cónsul británico de Palma de Mallorca quien, en 1940, informaba a Londres de que aquellos que dependían del racionamiento para sobrevivir "sufrían de diarrea, algo que es atribuido al pan, compuesto principalmente de salvado". ${ }^{53}$

Es difícil valorar las consecuencias que el racionamiento tuvo para los cuerpos de los más humildes. Es imposible ofrecer números completamente fiables y definitivos. Recientes estudios regionales detectan una caída en las tallas durante los años de posguerra en los mozos pertenecientes a clases sociales más bajas. ${ }^{54}$ Hace tiempo, un historiador tan moderado como Payne estimó que 200.000 españoles murieron de hambre como consecuencia de la política económica de la dictadura..$^{55}$ No obstante, no sabemos cuántas enfermedades y muertes fueron consecuencia de los efectos del sistema autárquico sobre los más débiles. No hablar de ellas sería silenciar una parte vital de la represión socioeconómica del franquismo. Fue común, por ejemplo, la aparición del "edema del hambre". En la España meridional, en los inviernos de 1940-1942 comenzaron a verse personas con las extremidades o el abdomen hinchados por la aparición del edema. Ante el peligro a la muerte, muchos comenzaron a alimentarse de productos no aptos para la salud. En Esparraguera (Barcelona) se detectó una extraña epidemia (latirismo) en los varones jóvenes, por la que sus piernas quedaban paralizadas; habían comido almortas, porque no tenían otra cosa que echarse a la boca. ${ }^{56}$

Una realidad de la España de aquellos años fueron las colas. Todavía perviven en la memoria de muchos españoles, asociadas al racionamiento: "teníamos que ir a la cola del pan, a la cola de la leche, a la cola del aceite, a la cola de los huevos, a todas las colas". ${ }^{77}$ Comenzaban de madrugada. Silenciosamente, hombres y mujeres esperaban al día unos tras otros, frente a las Delegaciones de Abastecimientos para ver revisada su cartilla, o frente a los comercios que distribuían los artículos con la esperanza de conseguir a precio oficial el producto con mejor calidad o, incluso, aguardando con paciencia antes de que los alimentos racionados llegasen a su fin. Es

\footnotetext{
${ }^{53}$ TNA, PRO, FO 371/24509. Informe sobre suministro de alimentos en España. 19-11-1940.

${ }^{54}$ PUCHE-GIL, Javier: "Guerra Civil, autarquía franquista y bienestar biológico en el mundo rural valenciano (1936-1949)", Historia Agraria, 52 (2010), pp. 129-162.

${ }_{55}$ PAYNE, Stanley: The Franco Regime, 1936-1975. Madison, University of Wisconsin Press, 1987, p. 252.

56 ABELLÁ, Rafael: Por el Imperio... pp. 124-126.

${ }^{57}$ UMBRAL, Francisco. Memorias de un niño de derechas. Barcelona, Destino, 1976, p. 31.
} 
cierto que las colas fueron un espacio donde muchos mostraron su recelo y malestar hacia el régimen y un sistema de racionamiento que consideraban injusto y perjudicial para ellos. El franquismo se preocupó por el comportamiento de las multitudes, como pudo suceder en la ciudad de Málaga en 1941, donde se recurrió "a las fuerzas de mando" para la vigilancia de las mismas. ${ }^{58}$ Pero en realidad aquellas interminables colas fueron también espejo del sistema represivo del régimen: en ellas se evidenciaba que las preocupaciones políticas de la población habían quedado silenciadas por la imperiosa necesidad de sobrevivir. Cada día, el régimen franquista forzaba a los más humildes a acudir de forma monótona a por su racionamiento, desmovilizando a la población y ejerciendo un control social sin precedentes. A través del racionamiento alimenticio, el poder soberano se cernía sobre los cuerpos, controlando los comportamientos cotidianos y la supervivencia de muchos españoles..$^{59}$

Otro elemento clave para comprender la sociedad de posguerra y el universo represivo que la rodeó fue, sin lugar a dudas, el fenómeno del estraperlo o mercado negro. Este "intruso cotidiano", consecuencia de la intervención económica autárquica, fue una práctica tan generalizada que aún hoy queda grabado en la memoria de nuestros mayores. ${ }^{60}$ Desde hace tiempo ha preocupado a la historiografía del franquismo; ${ }^{61}$ pero ha sido más o menos recientemente cuando se ha ahondado en las implicaciones del fenómeno para la consolidación del régimen franquista. Así, ha sido descrito como una verdadera "arma política" en manos de las autoridades del régimen. ${ }^{62}$ Las instituciones franquistas practicaron una política de tolerancia con sus apoyos sociales, permitiendo enriquecimientos sin precedentes o sortear las brutales dificultades de la España de posguerra. Mientras tanto, castigaron el estraperlo de los pobres, las pequeñas transacciones o ventas de productos de primera necesidad en pequeñas cantidades, pese a que esas mismas autoridades reconocían una y otra vez que la vida no era posible sin recurrir al mercado negro.

El perfil del estraperlista perseguido por el "Nuevo Estado" será el de hombres y mujeres humildes, sin prácticamente medios de vida, pertenecientes a los grupos sociales más modestos. Investigaciones realizadas para la provincia de Almería y Málaga muestran esta tendencia. Jornaleros, obreros, personas en paro, viudas como consecuencia de la guerra, mujeres casadas pero con su marido en la prisión o en un campo de trabajadores... La Guardia Civil o la policía los sorprenderá viajando en trenes, caminando de madrugada por caminos secundarios o practicando la venta ambulante. En la mayoría de los casos transportarán pequeñas cantidades de artículos como pan, aceite o tabaco. Caerá entonces todo el peso de la ley franquista: al deco-

${ }^{58}$ Archivo Histórico Provincial de Málaga (AHPM), Gobierno Civil. Orden público. Caja 12510, 28-6-1941.

${ }^{59}$ FOUCAULT, Michel: Hay que defender la sociedad. Madrid, Akal, 2004, pp. 212 y ss.

${ }^{60}$ DE VILALLONGA, José Luis: "El día que entré en Barcelona", en ESPADA, Arcadi (ed.): Dietario de Posguerra. Barcelona, Anagrama, 1998, p. 19.

${ }^{61}$ BARCIELA, Carlos: "El «estraperlo» de trigo en la posguerra", Moneda y Crédito, 151 (1981), pp. 17-37; BARCIELA, Carlos: "El mercado negro de productos agrarios en la posguerra, 1939-1953", en FONTANA, Josep (ed.): España bajo el franquismo. Barcelona, Crítica, 1986.

${ }^{62}$ DEL ARCO BLANCO, Miguel Ángel: "El estraperlo: pieza clave en la estabilización del régimen franquista". Historia del Presente, 15 (2010), pp. 65-78. 
miso de la mercancía, se le sumará la pena de multas en metálico a la que, en muchos casos debido a su comprometida situación económica, no podían hacer frente. Les esperaba entonces un triste destino en campos de trabajo hasta redimir su pena. ${ }^{63}$

Sobre todos ellos caerá la actuación de la Fiscalía de Tasas, institución constituida para la persecución de estos delitos económicos. Pocas veces un organismo estatal ha sido más odiado en la Historia de España. Tal como reconocía un gobernador civil en 1946, la Fiscalía había "batido el máximo de impopularidad que se registra en la historia de las leyes españolas". ${ }^{64}$ La población era consciente que la actuación de sus agentes provocaba la desaparición de los productos del mercado negro y disparaba al alza los precios. Pero además, el pueblo tenía claro que los agentes de la Fiscalía centraban su actuación sólo sobre el pequeño estraperlo, mirando hacia otro lado en lo referente a las grandes transacciones en el mercado negro. Así, los más desfavorecidos concebían su actuación como parte de la política represiva. Ello sucedía en León, donde los funcionarios de abastos y de la Fiscalía eran "mal mirados" por gran parte de la sociedad. ${ }^{65}$ Un parte de opinión sobre la provincia de Alicante en 1945 reconocía que continuaban las críticas de la población "a la actuación de la Fiscalía de Tasas", que consideraba que eran "sus mismos agentes" los que "realizan las operaciones más censurables" en el mercado negro. ${ }^{66}$

Los agentes de la Fiscalía no estaban solos. El régimen alentaba a la colaboración para la persecución de los delitos de tasas, premiando incluso a los delatores. Obviamente, en el clima de represión y asfixia impuesta por el "Nuevo Estado", pocos eran los que denunciaban a los grandes estraperlistas con conexiones en las instituciones. Pero no eran pocos los que sí denunciaban a los desamparados pequeños estraperlistas. En Níjar (Almería), se descubrió en 1941 que un vecino de la localidad trabajaba codo con codo con el Delegado Local de Información de Falange, denunciando a diversos vecinos y participando "a medias de las multas que imponían las Fiscalías de Tasas por las denuncias efectuadas por el vecino" ${ }^{67}$ Eran comunes las circulares y órdenes animando a la colaboración civil y de las autoridades en la denuncia y persecución de delitos de estraperlo. ${ }^{68} \mathrm{Y}$ surtían efecto: en la provincia de Málaga, el 36 por 100 de los expedientes incoados en 1942 habían tenido como origen una denuncia

${ }^{63}$ GÓMEZ OLIVER, Miguel y DEL ARCO BLANCO, Miguel Ángel: "El estraperlo: forma de resistencia y arma de represión en el primer franquismo", Studia Histórica. Historia Contemporánea, 23 (2005), pp. 179-199; BARRANQUERO, Encarnación y PRIETO Lucía: Así sobrevivimos al hambre: estrategias de supervivencia de las mujeres de la posguerra española. Málaga, Diputación Provincial de Málaga, 2003, pp. 221-235; RODRÍGUEZ BARREIRA, Óscar J: Migas con miedo..., pp. 230 y ss.

${ }^{64}$ AGA, Presidencia del Gobierno. Caja 20676, 27-3-1946.

${ }^{65}$ Informe de la Dirección General de Seguridad. León, mayo de 1942, en: Documentos inéditos para la historia del Generalísimo Franco. Vol. III. Madrid, Fundación Nacional Francisco Franco, 1993, p. 522.

${ }^{66}$ AGA, Cultura. Vicesecretaría de Educación Popular. Caja 21/1795, parte de opinión de la provincia de Alicante, 5-1-1945.

${ }^{67}$ AGA, Presidencia del Gobierno. Caja 20564, Parte mensual Almería (octubre, 1941).

${ }^{68}$ Ejemplo: Circular 13-1-1943 del Gobierno Civil de Málaga (Boletín Oficial de la Provincia de Málaga, 14-1-1943), en la que se excitaba el celo de los agentes para la represión y denuncias de infracciones de tasas. 
particular. ${ }^{99} \mathrm{~A}$ veces la delación venía de la mano del desinterés y el compromiso político. Pudo ser el caso de un teniente caballero mutilado de Estepona (Málaga), que renunció a favor del Auxilio Social de la localidad a la participación del 40 por 100 que le correspondía por denunciar a un vecino por estraperlo..$^{70}$

Para comprender la profundidad y dureza de la represión socioeconómica, debemos mirar más allá de las cartillas de racionamiento y del estraperlo. Hubo más ámbitos en los que el franquismo reprimió los destinos de los vencidos. Uno de ellos fue el mundo del trabajo. Influido por las tendencias fascistizantes de la Europa de entreguerras, el "Nuevo Estado" creó un marco laboral donde obreros y patronos quedaron encuadrados en un sindicato vertical. Liquidó los sindicatos y asociaciones que, desde finales del siglo XIX, habían contribuido de manera decisiva a la mejora de las condiciones laborales y salarios de los obreros, pero también al avance mismo de la democracia..$^{71}$ Las condiciones laborales cayeron en picado: congelación y bajada de salarios, trabajo a destajo, despidos indiscriminados, aumento de la jornada laboral... ${ }^{72} \mathrm{Si}$ contemplamos los avances que, a través tanto del sindicalismo como de la participación política, la izquierda había provocado en el mundo del trabajo en las décadas precedentes al franquismo, comprendemos claramente el frenazo que supuso la política laboral franquista en los derechos de las clases trabajadoras, tan identificadas con la II República y, por tanto, con los vencidos.

La represión socioeconómica también se evidenció en la vida cotidiana. Las clases trabajadoras sufrieron con toda su dureza las consecuencias de la política autárquica y, además de estar desarmados de cara a la negociación de sus condiciones de trabajo y salarios, sintieron los efectos del pésimo racionamiento, de la carencia generalizada de productos y del alza de los precios de unos artículos a los que no podrían hacer frente. Hambre y condiciones de trabajo se daban la mano, provocando incluso el descenso de los rendimientos de los obreros. En 1941, la producción minera en la zona de Huelva se estaba viendo reducida por "la imposibilidad física de los mineros de trabajar a pleno rendimiento"; en Sevilla, los obreros de los muelles del Guadalquivir tenían el mismo hándicap, no pudiendo efectuar la carga y descarga de los barcos "con la misma rapidez que antes". ${ }^{73}$ Por otro lado, el pasado político determinaba también el futuro en el mundo laboral: el régimen no sólo impulsó una política de depuraciones de empleados y funcionarios, sino que tanto en el mundo urbano como en el rural los obreros y campesinos con un pasado político izquierdista quedaron sin trabajo. En la provincia de Granada, por ejemplo, fueron numerosos los casos de "revancha patronal" sobre obreros y jornaleros. En Cataluña incluso se han

\footnotetext{
${ }^{69}$ AHPM, Gobierno Civil. Fiscalía Provincial de Tasas. Caja 12576, 30-12-1942.

${ }^{70}$ AHPM, Gobierno Civil. Fiscalía Provincial de Tasas. Caja 12576, 11-10-1941.

${ }^{71}$ Una visión transversal para Europa: ELEY, Geoff: Forging Democracy. The History of the Left in Europe, 1850-2000. Oxford, Oxford University Press, 2002.

${ }^{72}$ Una clásica visión general de todo el periodo: MOLINERO, Carme y YSÁS Pere: Productores disciplinados y minorías subversivas. Clase obrera y conflictividad laboral en la España franquista. Barcelona, Siglo XXI, 1998.

${ }^{73}$ TNA, PRO, FO 371/26890. Conditions in Seville district, 8-2-1941.
} 
atestiguado casos de empleadas de hogar despedidas por el mero hecho de que su marido era considerado "rojo". ${ }^{74}$

El franquismo dispuso, compensó y ayudó a aquellos que lucharon por él durante la Guerra Civil. Así, son conocidas las medidas para colocar a caballeros mutilados y excombatientes, la concesión de pensiones a ellos o a sus viudas, o la asignación de viviendas a quienes habían luchado por la "Causa Nacional". ${ }^{75}$ Sin embargo, no hubo tales medidas de gracia para los vencidos. Gerald Brenan, al volver a España tras la guerra en la segunda mitad de los años cuarenta, escribió sobre aquellos "que se arrastran por las calles sin brazos o piernas", argumentando que el gobierno concedía pequeñas pensiones a los mutilados de "su lado, pero aquellos que estuvieron comprometidos con los rojos, incluso si eran mujeres o niños, no obtenían ninguna ayuda". ${ }^{76}$

La represión socioeconómica se extendía a cualquier ámbito de la vida de los años cuarenta. Hasta aquí hemos rastreado algunos de los trazos que pueden parecer menos evidentes y visibles. Pero no hay que olvidar una serie de medidas e instituciones nacidas por la voluntad explícita del régimen de atacar el patrimonio y el futuro de los vencidos y de sus familias. Ya durante la guerra, en el mundo rural se produjo una auténtica "contrarrevolución agraria": de forma espontánea y desde las instituciones, los colonos asentados por la República fueron despojados de sus propiedades y bienes de labranza. ${ }^{77}$ También en esos días aparecieron las Comisiones de Incautación de Bienes, con el fin de intervenir y controlar los bienes y propiedades de los "desafectos" al golpe de estado. ${ }^{78}$ En los últimos meses de la contienda quedó instituido el Tribunal de Responsabilidades Políticas, verdadero símbolo de la represión socioeconómica. Nació con la voluntad explícita de castigar a aquellos que militaron en algún partido vinculado al Frente Popular desde 1934, incautando sus bienes y liquidando, no ya su futuro, sino el de su familia. Además, podía dictaminar el cese de su actividad profesional o incluso el traslado del inculpado a otros lugares

${ }^{74}$ ORTEGA LÓPEZ, Teresa María: Del silencio a la protesta. Explotación, pobreza y conflictividad en una provincia andaluza, Granada 1936-1977. Granada, Universidad de Granada, 2003, p. 71. MOLINERO, Carme y YSÁS Pere: Patria, Justicia y Pan. Nivell de vida i condicions de treball a Catalunya, 1939-1951. Barcelona, La Magrana, 1985, pp. 93-95.

${ }^{75}$ Una interesante reflexión sobre los excombatientes, su experiencia de guerra y su papel en el "Nuevo Estado" en: ALCALDE FERNÁNDEZ, Ángel: "Excombatientes en los poderes locales del primer franquismo (Zaragoza, 1939-1945). Experiencia de guerra e interpretación del apoyo social a la dictadura", Actas del X Congreso de la Asociación de Historia Contemporánea, Santander, 2010, Santander, Universidad, 2011.

${ }^{76}$ BRENAN, Gerald: The Face of Spain. Serif, London, 2010, p. 43.

77 BARCIELA, Carlos: "La contrarreforma agraria y la política de colonización del primer franquismo, 1936-1959", en GARCÍA SANZ, Ángel y SANZ FERNÁNDEZ, Jesús: Reformas y politicas agrarias en la historia de España. Madrid, MAPA, 1996, pp. 357-361; RIESCO, Sergio: "Una reflexión sobre la contrarreforma agraria como medio represivo". Hispania Nova, 6 (2006).

${ }^{78}$ Un buen estudio regional: ÁLVARO DUEÑAS, Manuel: "Control político y represión económica en el País Vasco durante la Guerra Civil: la comisión provincial de incautación de bienes de Vizcaya", Historia Contemporánea, 18 (1999), pp. 383-403. Una visión de conjunto: ÁLVARO DUEÑAS, Manuel, "Control político y represión económica”, NÚÑEZ DÍAZ-BALART, Mirta (Coord.), La gran represión. Los años de plomo del franquismo, Barcelona, Flor del Viento, 2008, pp. 251-262. 
de la geografía nacional, limitando también así sus posibilidades de sobrevivir y salir adelante en la penosa posguerra. ${ }^{79} \mathrm{Un}$ instrumento de menor importancia en la represión socioeconómica, no por su menor dureza sino porque alcanzó a menos republicanos, fue el Tribunal Especial para la Represión de la Masonería y el Comunismo. Aquellos que pertenecían a la "masonería, el comunismo u otras sociedades secretas" eran castigados con la prisión y con la pérdida de sus empleos; pero además, ellos y sus familias podían perder sus bienes, pues al ser inculpados también eran juzgados por el Tribunal de Responsabilidades Políticas. ${ }^{80} \mathrm{Y}$ finalmente, no hay que olvidar la represión administrativa: gran número de funcionarios calificados de "desafectos" fueron separados de sus puestos. La mayoría de ellos fueron sometidos a depuraciones, para lo que fue clave la colaboración ciudadana a la hora de ofrecer avales de su conducta o, también, dar pie a su condena. ${ }^{81}$

En definitiva, la represión socioeconómica acorralaba a los vencidos. Con su sustento en manos de un sistema de racionamiento, obligados a la práctica de estraperlo para sobrevivir, despojados de sus bienes, de sus empleos y de su libertad, los que habían apoyado la República estaban atrapados en el laberinto represivo del franquismo. Su lucha por la supervivencia fue espejo de su resistencia ante la brutalidad del régimen; pero también fue la mejor prueba de la desmovilización política que el "Nuevo Estado" consiguió mediante todas sus múltiples armas represivas.

\section{Conclusión}

El franquismo no renunció a la represión en sus casi cuarenta años de existencia. Por supuesto, con el paso del tiempo, ésta fue cambiando su apariencia y su intensidad, pero no varió sus objetivos. Aquellos que formaban parte de la "anti-España", quienes estaban relacionados con II República y todos los que se oponían a los postulados del régimen fueron víctimas de la represión franquista. Sin lugar a dudas, fueron los años de posguerra el escenario idóneo para mantener engrasada toda la maquinaria represiva sobre los que habían perdido la contienda. En medio de una España asolada por la miseria y rodeada del caos internacional, la "Cultura de la Victoria" barrió el territorio nacional de todos los "elementos indeseables" para el "Nuevo Estado". Mientras unos eran fusilados en las tapias de los cementerios o malvivían cruelmente hacinados en las cárceles de Franco, otros muchos veían cómo su papel de "rojos" les

${ }^{79}$ ÁLVARO DUEÑAS, Manuel: "Por ministerio de la ley y voluntad del Caudillo". La Jurisdicción Especial de Responsabilidades Politicas (1939-1945). Madrid, Centro de Estudios Políticos y Constitucionales, 2007, pp. 97-121.

${ }^{80}$ PORTILLA, Guillermo: La consagración del Derecho penal de autor durante el franquismo. El Tribunal Especial para la Represión de la Masonería y el Comunismo. Granada, Comares, 2010, p. 34-35.

${ }^{81}$ CUESTA, Josefina (dir.): La depuración de funcionarios bajo la dictadura franquista (19361975). Madrid, Fundación Francisco Largo Caballero, 2009, pp. 15-18. El interesante ejemplo de los jueces: FERNÁNDEZ-CREHUET, Federico: Jueces bajo el franquismo. Once historias (y una nota sobre la depuración de los funcionarios judiciales). Granada, Comares, 2011. 
granjeaba el desprecio de sus vecinos, les cerraba las puertas del mercado laboral o les hacía más difícil aún su supervivencia en tiempos de hambre.

El castigo físico de los vencidos no fue la única cara -aunque sí la más atroz- del sistema represivo franquista. La "justicia de Franco" también se mostró implacable en las esferas públicas y privadas, imponiendo los símbolos de la "Nueva España" a los derrotados y eliminando cualquier atisbo de liberalismo y democracia o adentrándose en los hogares de los españoles para modelar sus conductas. El incienso de la Iglesia y el azul de las camisas falangistas invadieron las calles de una España destrozada por tres años de conflagración. Los perdedores de la misma, debieron soportar el desprecio por parte de sus vecinos, la constante vigilancia de las autoridades locales o el miedo a ser denunciados por sus conciudadanos.

Los efectos derivados de la represión social, económica y cultural de los vencidos fueron coherentes con las aspiraciones de los vencedores. Es por ello que estas tres esferas de la represión deben ser entendidas de forma integrada y complementaria. Para buena parte de la sociedad, la penitencia impuesta a los perdedores de la guerra estaba justificada por los males sufridos, por el daño que le habían hecho a España y por la pérdida de algún familiar a mano de las "hordas marxistas". El destino de los "rojos" en la España de posguerra también era coherente con la naturaleza de la dictadura. Silenciados, humillados, sin bienes ni recursos, desolados por la muerte de sus familiares o su encarcelamiento, sin trabajo, obligados a vivir en ocasiones fuera de la legalidad... fueron condenados de por vida por un Estado en el que estaba prohibido hablar de reconciliación. Mientras que sus voces quedaban apagadas, el régimen del general Franco seguiría incólume hasta la muerte del dictador. 